DOI : $10.14746 /$ rie.2015.9.32

Uniwersytet im. Adama Mickiewicza w Poznaniu

\title{
Kultura i dyplomacja kulturalna Unii Europejskiej na przykładzie Programu „Kreatywna Europa”. Analiza politologiczna
}

\author{
Wstęp
}

\section{Cele naukowe}

Celem niniejszego artykułu jest naukowa analiza wpływu kultury i dyplomacji kulturalnej Unii Europejskiej na pobudzanie i stymulowanie procesu integracji Europy, który pozostaje dziś w nieustannym zaburzeniu i braku stabilności. Cel ten wpisuje się w problemowe podejście do unijnych strategii zmiany i rozwoju (w tym strategii „Europa 2020" - na rzecz inteligentnego i zrównoważonego rozwoju sprzyjającego włączeniu społecznemu), które zakładają realizację wielu nowych unijnych wspólnotowych inicjatyw i rozwiązań praktycznych, także tych dotyczących sektora kultury oraz sektora kreatywnego i audiowizualnego.

W komunikacie Komisji Europejskiej dotyczącym strategii „Europa 2020” określono sposób, dzięki któremu gospodarka Unii stanie się inteligentna i zrównoważona. Założono, że Unia Europejska po roku 2020 gotowa będzie sprzyjać włączeniu społecznemu i przyczyniać się będzie do osiagnnięcia wysokiego stopnia zatrudnienia i wydajności oraz większej spójności społecznej. Aby to było realne Unia musi zapewnić bardziej atrakcyjne warunki ramowe dla innowacji i kreatywności. Pod tym względem sektor kultury oraz sektor kreatywny i audiowizualny są źródłem nowatorskich pomysłów, które mogą zamienić się w produkty i usługi przyczyniające się do wzrostu gospodarczego i tworzenia miejsc pracy, pomagając stawić czoła kryzysowi i problemom społecznym. Nie ulega przecież wattpliwości, że wybitność i konkurencyjność w tych sektorach to przede wszystkim wynik wysiłków podejmowanych przez artystów, twórców i specjalistów, które UE musi propagować/upowszechniać. W tym celu poprawiany ma być dostęp sektora kultury oraz sektora kreatywnego i audiowizualnego do środków finansowych, co zostanie wykazane w poniższym tekście (Komunikat Komisji, s. 2).

$\mathrm{Z}$ uwagi na powyższe kultura i dyplomacja kulturalna wpisują się w paradygmat integracji progresywnej, która wykracza poza cele stricte gospodarcze i polityczne.

Podjęty temat badawczy jest tym bardziej ważny, gdyż kryzys gospodarczy i społeczny w Europie rozprzestrzenia się również na świat kultury. Identyfikujemy tu kata$\log$ trudno rozwiązywalnych problemów związanych z rozdrobnieniem sfery kultury i jego wytworów, globalizacją i digitalizacją, niedoinwestowaniem, niewłásiwą 
ochroną własności intelektualnej i praw autorskich oraz niewystarczającą międzynarodową współpracą kulturalną. Europa kultury zderza się ze zwiększoną konkurencyjnością, szczególnie tą pochodzącą ze Stanów Zjednoczonych i Azji (Japonia, Chiny). Słabe rezultaty uzyskują działania służące budowaniu potencjału i wspieranie transnarodowego obiegu dzieł kultury. Unii Europejskiej nie udaje się też wypełnianie jej zobowiązań prawnych w zakresie ochrony i promowania różnorodności kulturowej i językowej.

\section{Odniesienia empiryczne}

Egzemplifikacją empiryczną badanego tematu będzie tu unijny program wsparcia finansowego „Kreatywna Europa”. Jest to nowa inicjatywa Komisji Europejskiej, oferująca wsparcie finansowe dla sektorów: kultury, kreatywnego i audiowizualnego na lata 2014-2020. Te siedem lat będzie niezwykle istotne z punktu widzenia konieczności poprawy włączenia społecznego i kulturowego oraz zatrudnienia i wzrostu w Europie. $Z$ tego względu program ten stanowi początek nowego systemu wsparcia UE $m$.in. dla kina, telewizji, muzyki, literatury, sztuk widowiskowych (teatru), dziedzictwa kultury oraz dziedzin pokrewnych.

\section{Uwarunkowania terminologiczne i metodologiczne}

W niniejszym artykule nie zabraknie odniesień do podstawowych pojęć i wyjaśnień z zakresu obszaru badawczego kultury i dyplomacji kulturalnej.

Pojęcie kultury jest złożonym problemem badawczym. Kultura desygnuje wiele definicji i znaczeń. Kulturę tworzą ludzie (jednostki, obywatele), narody, społeczeństwa, samorządy, grupy i wspólnoty, a także organizacje i instytucje - rozwijając ją na różnych szczeblach aktywności współczesnej cywilizacji. Tak postrzegana kultura jest ważnym czynnikiem rozwoju ogólnospołecznego, stabilności (równowagi) i rozwoju. Cywilizacja i kultura pozostają we wzajemnych interakcjach. Tam, gdzie poziom kultury jest wyższy, tam też bardziej jest rozwinięta aktywność (przestrzeń) cywilizacyjna. Tam, gdzie sfera kultury wykazuje niedorozwój, towarzyszący jej świat przeżywa kryzys. Braki w dziedzinie kultury, zwłaszcza brak racjonalności w gospodarowaniu jej zasobami powoduje nierówności i konflikty, doprowadzając w efekcie do poważnych perturbacji (Bednarek, 2002, s. 315).

"Sektor kultury i sektor kreatywny" w regulacjach unijnych oznaczają wszystkie sektory, których działalność opiera się na wartościach kulturowych lub na artystycznej i innej twórczej ekspresji, niezależnie od tego, czy ta działalność ma charakter zorientowany na rynek, bez względu na rodzaj struktury, w ramach której jest ona prowadzona, oraz niezależnie od sposobu finansowania tej struktury. W zakres tej działalności wchodzi rozwój, tworzenie, produkcja, rozpowszechnianie i ochrona dóbr i usług zawierających elementy kulturalnej, artystycznej lub innej twórczej ekspresji, a także funkcje pokrewne, takie jak edukacja lub zarządzanie. Sektor kultury i sektor kreatywny obejmują między innymi architekturę, archiwa, biblioteki i muzea, rękodzieło artys- 
tyczne, sektor audiowizualny ( $w$ tym film, telewizje, gry wideo i multimedia), materialne i niematerialne dziedzictwo kulturowe, wzornictwo, festiwale, muzykę, literaturę, przedstawienia artystyczne, działalność wydawnicza, radio i sztuki wizualne (Rozporzq̨dzenie Parlamentu, s. 2).

To polityka kulturalna UE i jej dyplomacja kulturalna stwarza dziś okazję do dzielenia się z innymi krajami europejską kulturą $i$ jej wartościami, takimi jak prawa człowieka, różnorodność i równość.

Jest ona także korzystna z punktu widzenia miejsc pracy i rozwoju/wzrostu gospodarczego (Dyplomacja kulturalna, s. 3-8).

Unijna kultura i dyplomacja kulturalna w ideale liberalnym (pluralistycznym) to autentyczne katalizatory kreatywności prowadzące do rozwoju wiedzy na temat wartości fundujących wspólnotę europejską oraz służące aktywizacji społecznej obywateli UE. Przyczyniają się też do lepszego zrozumienia i wzmacniania procesów integracji europejskiej i spójności społeczno-kulturowej.

Z punktu widzenia analitycznego i metodologicznego dla Autorki niniejszego tekstu istotne jest udowodnienie czytelnikom, że kultura (polityka kulturalna) oraz dyplomacja kulturalna Unii Europejskiej i w Unii Europejskiej (realizowana przez 28 państw członkowskich) prowadzi do urzeczywistnienia celów integracji europejskiej poprzez wzmocnienie: - kapitału ludzkiego (kapitału społecznego); - międzynarodowej wymiany wiedzy i dóbr niematerialnych; - dialogu międzykulturowego; - wsparcia rozwoju społecznego wsi, miast i regionów europejskich.

\subsection{Transarodowość i transgraniczność kultury}

$\mathrm{Na}$ oddzielne potraktowanie zasługuje problematyka transnarodowości i transgraniczności. Zdajemy sobie sprawę że proces integracji europejskiej podlega nieodwracalnej bifurkacji. Jest to proces swoistej decentralizacji, w którym coraz większa część aktywności politycznej i prawotwórczej nie jest już inicjowana, podtrzymywana czy też kontrolowana przez państwa członkowskie UE. W rezultacie mamy do czynienia z podziałem na uczestników państwowych i niepaństwowych (transnarodowych i transgranicznych) i kreowaniem nowego typu uczestnictwa (często o charakterze nieekonomicznym) w procesie integracji (unifikacji i harmonizacji) Europy.

„Kurczenie się” Europy w wymiarach społecznym, gospodarczym i politycznym ogromnie ułatwiła i przyspieszyła kultura oraz wymiana wiedzy i obieg informacji, zwiększając tym samym współzależność narodów i społeczeństw. Kultura nie respektuje granic państw. Kultura przyspiesza proces dekoncentracji i decentralizacji. Kultura zmienia też świadomość i intensyfikuje samodzielne myślenie i działanie tak jednostek, jak i grup społecznych.

Gwałtowny rozwój stosunków transnarodowych i transgranicznych w sferze kultury sprawia, że państwa tracą nad nimi kontrolę. W konsekwencji wzrasta autonomia aktorów transnarodowych i transgranicznych, a tym samym poszerzają się możliwości działania niezależne od państw członkowskich UE. Granice między tym, co wewnątrzpaństwowe i tym, co międzynarodowe/europejskie/unijne ulegają wyraźnemu zatarciu. Stosunki między podmiotami transnarodowymi i transgranicznymi prowadzone z po- 
zycji poszukiwania wspólnego mianownika dla wyrażanych przez nie potrzeb, dążeń i interesów nabierają charakteru scalającego. Sprawiają, że zdecydowanie rozszerza się ich możliwość działania. Stosunki te zaczynaja pełnić niespotykane w przeszłości funkcje kulturowe oraz coraz częściej przyjmują zasięg transnarodowy i transgraniczny (Czachór, 2004, s. 33-35).

W sektorze kultury i sektorach kreatywnym i audiowizualnym znane jest pojęcie transnarodowego obiegu, które przypisuje się takim sferom aktywności jak:

- wspieranie dystrybucji dóbr kultury poprzez transnarodowy marketing, tworzenie marki, upowszechnianie i pokazy dzieł audiowizualnych;

- propagowanie transnarodowego marketingu, tworzenia marki i dystrybucji dzieł kultury we wszystkich dostęnych miejscach;

- wspieranie działań na rzecz rozwoju publiczności jako środka stymulującego zainteresowanie europejskimi dziełami kultury oraz poprawę dostępu do nich, w szczególności poprzez promocję, organizację imprez, popularyzację wiedzy na temat kultury i sztuki oraz organizację festiwali;

- promowanie nowych metod dystrybucji, aby mogły powstawać nowe modele biznesowe w kulturze i pozostałych sektorach.

W literaturze i aktach prawa UE spotyka się też określenie transnarodowego rozpowszechniania i mobilności. Chodzi tu o wspieranie: - międzynarodowych tournée, imprez, wystaw i festiwali; - rozpowszechniania dzieł kultury europejskiej z myślą o zagwarantowaniu jak najszerszej ich dostępności; - działań na rzecz rozwoju publiczności jako środka stymulującego i ułatwiającego dostęp do europejskich dzieł kultury i pracy twórczej oraz materialnego i niematerialnego europejskiego dziedzictwa kulturowego.

Na uwagę zasługuje też transnarodowa współpraca polityczna rozumiana jako:

- transnarodowa wymiana doświadczeń oraz wiedzy eksperckiej na temat nowych modeli biznesowych i modeli zarządzania;

- partnerskie uczenie się i tworzenie sieci między organizacjami sektora kultury oraz sektora kreatywnego i audiowizualnego oraz osobami odpowiedzialnymi za wyznaczanie kierunków polityki w zakresie rozwoju tych sektorów, propagując w stosownych przypadkach cyfrowe tworzenie sieci;

- gromadzenie danych rynkowych, prowadzenie badań, analizy rynku pracy i zapotrzebowania na umiejętności, analizy europejskiej i krajowej polityki kulturalnej i wspieranie badań statystycznych w oparciu o instrumenty i kryteria charakterystyczne dla każdego sektora oraz oceny obejmujące pomiar wszystkich aspektów wpływu;

- wnoszenie wkładu finansowego w celu wspomagania gromadzenia i analizy danych:

- wypróbowywanie nowych i międzysektorowych metod biznesowych w zakresie finansowania, dystrybucji twórczości i uzyskiwania z niej przychodów;

- organizacja konferencji, seminariów i prowadzenie dialogu politycznego, między innymi na temat umiejętności korzystania z kultury i z mediów (Rozporzadzenie Parlamentu, s. 3-4).

Wniosek z tego płynie następujący: z uwagi na wielokulturowość i wieloaspektowość integrującej się Europy propagowanie transnarodowej aktywności, w tym mobilności podmiotów sektora kultury oraz sektora kreatywnego i audiowizualnego będzie 
przyczyniać się do wzmacniania wspólnej przestrzeni kulturowej. Pośrednio oddziaływać to będzie na transnarodowe rozpowszechnianie dziel i produktów kultury oraz pozostałych sektorów, a tym samym promowanie wymian kulturowych i dialogu międzykulturowego. Przykładem niech tu będą takie transnarodowe inicjatywy jak: - Europejska Stolica Kultury; - Znak Dziedzictwa Europejskiego; - Europejskie Dni Dziedzictwa. Niezmiernie też ważne są transnarodowe i transgraniczne nagrody europejskie takie jak: - nagroda UE w dziedzinie dziedzictwa kulturowego/nagroda „Europa Nostra”; - nagroda UE w dziedzinie architektury współczesnej; - Europejska Nagroda Literacka; - nagroda European Border Breakers; - nagroda „Media” Unii Europejskiej.

\section{Europejska wartość dodana}

Europejską wartość dodaną w zakresie kultury i sektorów kreatywnego i audiowizualnego uzyskuje się w Unii Europejskiej poprzez:

- transnarodowy charakter działań stanowiących uzupełnienie programów regionalnych, krajowych, międzynarodowych oraz innych programów i polityk Unii oraz wpływ tych działań na sektor kultury i sektor kreatywny/audiowizualny oraz na obywateli i ich wiedzę na temat kultur odmiennych od ich wlasnych;

- rozwój i propagowanie współpracy transnarodowej pomiędzy podmiotami sektora kultury oraz sektora kreatywnego i audiowizualnego, w tym pomiędzy artystami oraz osobami zawodowo związanymi, organizacjami oraz podmiotami, skupiającej się na stymulowaniu bardziej kompleksowego, szybkiego, skutecznego i długoterminowego reagowania na globalne wyzwania;

- korzyści skali i masę krytyczna, którym sprzyja wsparcie udzielane przez Unię i które przyczyniają się do powstawania większych możliwości pozyskiwania dodatkowych środków finansowych (efekt dźwigni);

- zapewnianie bardziej wyrównanych szans w europejskim sektorze kultury i sektorze kreatywnym/audiowizualnym poprzez uwzględnianie sytuacji państw o niższej wydajności produkcyjnej lub państw bądź regionów o niewielkim obszarze geograficznym lub językowym.

\section{Europejski/unijny wymiar kultury}

\section{Uwarunkowania regulacyjne}

Zgodnie z treścią Traktatu o Unii Europejskiej każdy obywatel ma prawo uczestniczyć w życiu demokratycznym i kulturalnym, a państwa członkowskie i instytucje Unii powinny umożliwić obywatelom i stowarzyszeniom przedstawicielskim udział w świecie kultury oraz publiczną (otwartą) wymianę dóbr/wytworów kultury we wszystkich sektorach. Kultura i polityka kulturalna poprzez regularny dialog ze społeczeństwem obywatelskim i gospodarką służy inteligentnemu i zrównoważonemu rozwojowi, wspomaga wzrost gospodarczy i wzmacnia spójność społeczną. 
Natomiast Traktat o funkcjonowaniu Unii Europejskiej (TFUE) ma na celu tworzenie coraz ściślejszego związku między narodami Europy i powierza Unii zadania w zakresie, między innymi, przyczyniania się do rozkwitu kultur państw członkowskich, w poszanowaniu ich różnorodności narodowej i regionalnej, równocześnie podkreślając znaczenie wspólnego dziedzictwa kulturowego. W tym względzie Unia - jeśli to niezbędne - wspiera i uzupełnia działania państw członkowskich na rzecz pogłębiania wiedzy na temat kultury i historii narodów europejskich i ich upowszechniania. W związku z tym, w razie potrzeby, UE wspiera i uzupełnia działania państw członkowskich na rzecz poszanowania różnorodności kulturowej i językowej. Unia podejmuje się tych zadań z odwołaniem do art. 167 TFUE i konwencji UNESCO z 2005 r. w sprawie ochrony i promowania różnorodności form wyrazu kulturowego wzmocnienia konkurencyjności sektora kultury i sektora kreatywnego oraz ułatwienia przystosowania się do zmian w przemyśle (Rozporzq̨dzenie Parlamentu, s. 1).

TFUE ustanawia także obywatelstwo Unii, które uzupełnia obywatelstwo krajowe odpowiednich państw członkowskich oraz stanowi istotny element ochrony i wzmacniania procesu integracji europejskiej. Aby obywatele w pełni popierali integrację europejską, należy położyć większy nacisk na wspólne wartości, historię i kulturę, będące kluczowymi elementami uczestnictwa w społeczeństwie zbudowanym w oparciu o wolność, demokrację i szacunek dla praw człowieka, różnorodność kulturową i językową, tolerancję i solidarność (Decyzja Parlamentu Europejskiego, s. 1).

Z Karty Praw Podstawowych Unii Europejskiej, w szczególności jej art. 11, 21 i 22 wynika, że sektor kultury oraz sektor kreatywny/audiowizualny w istotny sposób przyczyniają się do zwalczania wszelkich form dyskryminacji, między innymi rasizmu i ksenofobii, i stanowią ważną platformę dla wolności wyrażania opinii i promowania poszanowania różnorodności kulturowej i językowej.

Wspomniana powyżej konwencja UNESCO z 2005 r., która weszła w życie w dniu 18 marca 2007 r. i której stroną jest Unia Europejska, podkreśla, że działalność kulturalna oraz dobra i usługi kulturalne mają znaczenie zarówno ekonomiczne, jak i kulturowe, ponieważ są nośnikami tożsamości, wartości oraz znaczeń, i w związku z tym nie powinny być traktowane jako mające wyłącznie wartość handlową. Konwencja ta ma na celu umacnianie współpracy międzynarodowej - między innymi poprzez zachęcanie do zawierania międzynarodowych umów o koprodukcji i współrozpowszechnianiu - oraz solidarności, by służyć tworzeniu środków wyrazu kulturowego we wszystkich krajach i przez wszystkich obywateli. Konwencja mówi także, że należy poświęcić uwagę szczególnym warunkom i potrzebom różnych grup społecznych, w tym członków mniejszości. Zatem zgodnie z konwencją program wsparcia dla sektora kultury i sektora kreatywnego powinien sprzyjać różnorodności kulturowej na poziomie międzynarodowym (Rozporzqdzenie Parlamentu, s. 1).

$\mathrm{Na}$ uwagę zasługuje też fakt, że w konkluzjach w sprawie służb informacyjnych ds. mobilności dla artystów i osób zawodowo zajmujących się kulturą Rada UE potwierdziła znaczenie mobilności artystów i osób zawodowo zajmujących się kulturą dla Unii i dla osiagnnięcia celów strategii „Europa 2020” oraz wezwała państwa członkowskie i Komisję Europejską, aby w ramach swych kompetencji i z uwzględnieniem zasady pomocniczości ułatwiały przekazywanie wyczerpujących i rzetelnych informa- 
cji artystom i osobom zawodowo zajmującym się kulturą, które pragną być mobilne w ramach Unii.

\section{Obywatel UE a europejski/unijny wymiar kultury}

Choć z bycia obywatelem Unii posiadającym określone prawa i obowiązki płyną obiektywne korzyści, UE i jej aktorzy instytucjonalni (w ujęciu traktatowym i pozatraktatowym) nie zawsze skutecznie eksponuje związek między rozstrzyganiem wielu problemów gospodarczych i społecznych a kulturą. Dlatego też imponujące osiagnięcia w postaci pokoju i stabilizacji w Europie, długoterminowego trwałego wzrostu gospodarczego, stabilnych cen, skutecznej ochrony konsumentów i środowiska oraz promowania praw podstawowych nie zawsze skutkują aktywnością europejską w sferze kultury.

Nie od dziś wiadomo, że aby zbliżyć kulturę do jej obywateli, a obywatelom umożliwić pełne uczestnictwo w jej tworzeniu i konsumpcji, należy podjąć różnorodne działania i skoordynowane wysiłki na szczeblu transnarodowym. Zaprezentowane i przeanalizowane w tym tekście inicjatywy i formy aktywności stanowią wyjątkową okazję ku temu, by umożliwić obywatelom UE bezpośrednie uczestnictwo w kształtowaniu kultury i dyplomacji kulturalnej. Aby to było możliwe ważne jest zbudowanie zdolności Unii do zwiększenia zainteresowania sprawami kultury na poziomie indywidualnym i osadzenie tego zainteresowania w kontekście lokalnym i regionalnym. Do tego dochodzi konieczność synergii z innymi aktywnościami Unii, ze szczególnym uwzględnieniem edukacji i nauki, szkolenia zawodowego, młodzieży, sportu, podstawowych praw i wolności, włączenia społecznego, równości płci, zwalczania dyskryminacji, badań i innowacji, społeczeństwa informacyjnego, rozszerzenia oraz działań zewnętrznych Unii.

Europejski wymiar kultury powinien obejmować szerokie spektrum różnorodnych działań, w tym spotkania obywateli UE, kontakty i debaty w kwestiach kulturalnych, imprezy na szczeblu Unii, inicjatywy uwrażliwiające i skłaniające do refleksji nad decydującymi momentami w historii kulturalnej Europy, inicjatywy uświadamiające obywatelom Europy, zwłaszcza młodym ludziom, historię kultury, a także debaty na temat polityki kulturalnej, z myślą ożywienia życia kulturalnego we wszystkich jego aspektach.

Należy zdać sobie sprawę jak cenna jest rola Unii Europejskiej w ułatwianiu, wymianie i propagowaniu inicjatyw służących zbiorowemu zaangażowaniu w sektorze kultury oraz sektorze kreatywnym i audiowizualnym. Oczywiście należy przy tym uwzględnić aspekty historyczne, kulturowe i międzykulturowe oraz istniejące związki między przeszłością narodową a tożsamością europejską.

Dlatego podejmowane działania powinny się wiązać z unijną agendą polityczną i należy o nich właściwie informować. Należy też zwrócić szczególną uwagę na zrównoważone włączanie obywateli i organizacji społeczeństwa obywatelskiego ze wszystkich państw członkowskich w transnarodowe projekty i działania oraz na ich zrównoważony udział w tych projektach i działaniach $\mathrm{z}$ uwzględnieniem wielojęzyczności Unii i potrzeby zaangażowania grup niedostatecznie reprezentowanych (Rozporzqdzenie Rady (UE)). 


\section{Europejska Agenda Kultury i instytucjonalny zakres polityki kulturalnej UE}

Wdrażanie praktyczne europejskiego wymiaru kultury musi być zgodne z wszelkimi strategiami lub politykami kulturalnymi państw członkowskich oraz z wszelkimi regionalnymi strategiami kulturalnymi (Decyzja $n r$ 1622). Aby było to możliwe zaproponowana została Europejska Agenda Kultury (EAK).

Jeżeli chodzi o genezę EAK warto wrócić do roku 2007, kiedy to władze krajowe, instytucje unijne i przedstawiciele sektora kultury w Unii Europejskiej zaczęły ściśle ze sobą współpracować po to, aby propagować różnorodność kulturową i dialog międzykulturowy. Uznały one wtedy kulturę jako: - istotny element systemu politycznego i społeczno-gospodarczego; - koło zamachowe twórczości i innowacji; - element stosunków/relacji zewnętrznych UE.

Wymienione tu trzy zakresy unijnego definiowania kultury znalazły się w komunikacie dotyczącym Europejskiej Agendy Kultury w dobie globalizacji świata, popartym przez Radę UE w rezolucji z dnia 16 listopada 2007 r. i przez Parlament Europejski w rezolucji z dnia 10 kwietnia $2008 \mathrm{r}$.

EAK ma na celu propagowanie różnorodności kulturowej i dialogu międzykulturowego, kultury jako katalizatora kreatywności na rzecz wzrostu i zatrudnienia oraz kultury jako istotnego elementu stosunków międzynarodowych Unii.

Podsumowując rozważania o europejskim wymiarze kultury raz jeszcze sprecyzujmy główne zadania w tej sferze dla Unii Europejskiej i jej instytucji. Po pierwsze chodzi o wzmocnienie współpracy w każdym sektorze kultury między operatorami w dziedzinie kultury, artystami z danego państwa członkowskiego i innych krajów. Po drugie istotne jest podkreślenie bogactwa różnorodności kulturowej w Europie, a także trwałość i stanowienie integralnej części długofalowego rozwoju kulturalnego i społecznego Europy. I po trzecie celem jest uwypuklenie wspólnych aspektów kultury europejskiej i wspieranie udziału mieszkańców w projektach z zakresu kultury.

Kultura jako ważny element stosunków zewnętrznych w ramach celów strategicznych Europejskiej Agendy Kultury staje się dziś ważnym elementem kompleksowych ram polityki, którymi kieruje się Komisja Europejska (w obecnej kadencji Komisji -2014-2019 - komisarzem do spraw edukacji, kultury, wielojęzyczności i młodzieży jest A. Vassiliou). Dodać tu można, że Komisja Europejska, korzystając ze swych kompetencji powierzyła Agencji Wykonawczej ds. Edukacji, Kultury i Sektora Audiowizualnego zadania w dziedzinie edukacji, kultury i sektora kreatywnego/audiowizualnego.

Kultura, pozostając też nadal domeną państw członkowskich sprawia, że władze krajów członkowskich mogą wyznaczać swoich przedstawicieli w ogólno-unijnych zespołach eksperckich, których celem jest omawianie i rozpowszechnianie przykładów wzorcowych rozwiązań krajowych i regionalnych. Eksperci mogą również proponować metody współpracy w obszarach priorytetowych.

\section{Europejska dyplomacja kulturalna}

Unia Europejska i jej państwa członkowskie mogą znacząco zyskać na stosowaniu metody dyplomatycznego przekonywania zwanej miękką siłą(soft power), jaką dyspo- 
nuje kultura, aktywność kulturalna i system wsparcia finansowego dla sektorów związanych z kulturą. Przynosi to korzyści gospodarce i społeczeństwu dzięki lepszemu dostępowi do rynku dla europejskiego sektora kultury oraz sektora kreatywnego i audiowizualnego, większej różnorodności kulturowej, a także szerszej wymianie wartości europejskich (Dyplomacja kulturalna, s. 2).

Unia Europejska dąży do zwiększenia efektów europejskiej dyplomacji kulturalnej poprzez:

- lepszą koordynację i specjalny personel (np. attaché kulturalny w delegaturach UE);

- nowe metody finansowania i pozyskiwania funduszy, w tym dotyczące współfinansowania i partnerstw publiczno-prywatnych;

- łączenie zasobów organizacji kulturalnych i państw członkowskich, zwłaszcza za pośrednictwem ich instytutów kultury i pracowników dyplomatycznych za granica;

- usuwanie przeszkód w mobilności, na przykład poprzez złagodzenie wymogów dotyczących wiz dla podmiotów działających w sektorze kultury;

- nawiązywanie kontaktów z młodymi ludźmi, na przykład poprzez poszerzenie zakresu programów wymiany edukacyjnej i kulturalnej;

- skupianie uwagi na dużych i małych miastach w celu określenia kluczowych partnerów;

- ułatwianie wymiany doświadczeń i najlepszych praktyk między artystami z różnych krajów, menedżerami kultury, dziennikarzami lub pisarzami;

- wzmacnianie pozycji lokalnych podmiotów sektora kultury poprzez ułatwianie współpracy z organizacjami kulturalnymi lub fundacjami;

- ulepszanie monitorowania i oceny projektów oraz strategii dyplomacji kulturalnej (Dyplomacja kulturalna, s. 6-9).

\section{Europejska kreacja kultury}

\section{Europejski sektor kreatywny}

Europejski sektor kreatywny/audiowizualny jest z natury zróżnicowany, a linie podziału wyznaczają aspekty narodowe $i$ językowe, co skutkuje bogatym pod względem kulturowym i w wysokim stopniu niezależnym krajobrazem kulturowym, dzięki czemu dopuszczone są do głosu różne tradycje kulturowe europejskiego dziedzictwa. Jednakże rozdrobnienie to prowadzi również do powstawania szeregu przeszkód na drodze do sprawnego transnarodowego obiegu dzieł kultury i pracy twórczej oraz do utrudniania mobilności podmiotów działających w sektorze kreatywnym i audiowizualnym w obrębie Unii i poza nią, co może skutkować brakiem równowagi geograficznej, a w konsekwencji przyczynić się do ograniczenia możliwości wyboru dla konsumentów (Rozporzq̨zenie Parlamentu).

Przejdźmy teraz do danych statystycznych. Przemysł kreatywny i audiowizualny w Europie sprzyja wzrostowi gospodarczemu, zatrudnieniu, innowacjom i spójności społecznej. Sektory te wytwarzają około 4,5 proc. unijnego PKB i zatrudniają około 3,8 proc. europejskich pracowników (czyli 8,5 mln osób). Łączne zatrudnienie w tej 
sferze rosło średnio o 3,5 proc. rocznie, w porównaniu ze wzrostem o 1 proc. rocznie odnotowanym w unijnej gospodarce ogółem. Europa jest więc światowym liderem w eksporcie produktów sektora kreatywnego. Aby utrzymać tę pozycję, musi inwestować w zdolność tych sektorów do działania poza granicami UE (Kreatywna Europa, s. 1).

Dla europejskiego sektora kreatywnego postęp techniczny (technologiczny) stanowi zarówno szansę, jak i wyzwanie. Unia Europejska stara się pomagać wszystkim osobom związanym z tym sektorem - od lokalnych społeczności zajmujących się ochroną miejscowego dziedzictwa po producentów filmów nagradzanych na festiwalach - aby umożliwić im wykorzystanie szans oraz pokonanie trudności. A wyzwania mogą być duże. W rozszerzonej Unii Europejskiej panuje większa różnorodność, lecz różnice językowe i kulturowe powodują też rozdrobnienie rynków. W dobie globalnego kryzysu gospodarczego finansowanie kultury jest coraz trudniejsze. Na tradycyjne metody dystrybucji ogromny wpływ mają nowe technologie cyfrowe - na przykład książki zamiast na bibliotecznych półkach można przechowywać na twardym dysku. W tej nowej sytuacji trudno jest stworzyć trwałe modele biznesowe (Zrozumieć, s. 2).

Unia Europejska zobowiązała się uwzględniać wyzwania powstałe na skutek globalizacji i technologii cyfrowych, które powodują zmianę sposobu tworzenia dóbr kultury, ich rozpowszechniania i udostępniania, i które prowadzą do przekształcenia modeli biznesowych i źródeł dochodów. Zmiany te stwarzają również nowe możliwości dla sektora kreatywnego. UE pozwala im na wykorzystanie tych możliwości, tak aby mogły one skorzystać na digitalizacji i by mogły powstawać w nich nowe miejsca pracy i międzynarodowe kariery. $Z$ drugiej strony sektor kreatywny nie wykorzystuje w pełni Rynku Wewnętrznego UE. Jednym z największych wyzwań, z jakimi musi zmagać się sektor, to rozdrobnienie rynku wynikające z różnorodności kulturowej i językowej. W Unii Europejskiej mamy 24 języki urzędowe, 3 różne alfabety, a także około 60 oficjalnie uznanych języków mniejszości i regionalnych. Ta różnorodność stanowi część bogactwa Europy, ale jednocześnie utrudnia autorom dotarcie do czytelników w innych krajach. Widzom kinowym lub teatralnym utrudnia oglądanie zagranicznych dziel, a muzykom - zdobywanie nowych słuchaczy. Z przeprowadzonego badania Eurobarometru wynika, że tylko 13\% Europejczyków chodzi na koncerty z udziałem artystów z innego kraju europejskiego, a jedynie 4\% ogląda sztuki teatralne z innego kraju w Europie (Survey shows, s. 1). Większy nacisk na wsparcie w zakresie zdobywania publiczności oraz zdolności sektorów do interakcji z odbiorcami, na przykład poprzez inicjatywy związane z umiejętnością korzystania z mediów lub nowe interaktywne narzędzia internetowe, może potencjalnie zwiększyć dostęp publiczności do zagranicznych dzieł (Kreatywna Europa, s. 3).

Nie można tu nie wspomnieć o empirycznym przykładzie, jakim jest Europejski Sojusz Sektora Kreatywnego (European Creative Industries Alliance), będący projektem pilotażowym. Stanowi on międzysektorową inicjatywę, która w pierwszej kolejności wspiera sektor kreatywny na poziomie polityki. Ma na celu mobilizację dodatkowych funduszy dla sektora kreatywnego oraz stymulowanie popytu na usługi tego sektora wśród pozostałych branż i sektorów. Dla lepszego wsparcia innowacji w sektorze kreatywnym wypróbowane zostaną nowe narzędzia, przekształcone następnie w platformę na rzecz uczenia się w zakresie polityki, która złożona będzie $\mathrm{z}$ europejskich, krajowych i regionalnych zainteresowanych podmiotów. 


\section{Program „Kreatywna Europa”}

Program „Kreatywna Europa” to jeden z nowych ramowych programów Unii Europejskiej zaplanowanych na lata 2014-2020. Jednym z proponowanych ogólnych celów programu jest wzmacnianie konkurencyjności sektora kultury i sektora kreatywnego w celu propagowania inteligentnego i zrównoważonego rozwoju sprzyjającego włączeniu społecznemu. Deklarowanym celem Programu jest zwiększenie zatrudnienia w sektorze kultury i sektorze przemysłów kreatywnych oraz zwiększenie udziału tych sektorów w PKB krajów członkowskich.

„Kreatywna Europa” przeznaczona jest dla wszystkich państw Unii Europejskiej oraz Islandii, Norwegii, Bośni i Hercegowiny, a także Albanii, Czarnogóry, Macedonii, Mołdawii, Serbii, Turcji, Gruzji w komponencie kultura. Program składa się z trzech czę́ci (komponentów). Są to: „Media”, „Kultura” i część międzysektorowa.

Z punktu widzenia twórców kultury najciekawszy jest niewątpliwie komponent „Media". Obszary grantowe w jego ramach to:

- producenci audiowizualni - rozwój projektów filmowych, gier video oraz produkcja telewizyjnych projektów filmowych;

- dystrybutorzy - schematy dystrybucyjne i agenci sprzedaży;

- kina - tworzenie sieci;

- targi, festiwale i szkolenia - dostęp do rynków, festiwale filmowe, szkolenia i warsztaty branżowe;

- organizatorzy wydarzeń - wsparcie dla projektów rozwijających widownię;

- fundusze koprodukcyjne - wsparcie międzynarodowych funduszy koprodukcyjnych (Czym jest, s. 2-4).

Komponent „Kultura” skierowany jest do instytucji, organizacji i innych podmiotów działających w sektorach kultury i kreatywnych. Jego celem jest promocja europejskiej kultury i sztuki, zwiększanie mobilności artystów i dzieł europejskich, budowanie współpracy kulturalnej na poziomie ponadnarodowym, rozwijanie europejskiej publiczności oraz dostosowywanie sektorów kultury i kreatywnych do technologii cyfrowych i wdrażania innowacji (Czym jest, s. 2-4).

„Kultura” oferuje cztery obszary grantowe takie jak:

- projekty współpracy europejskiej;

- sieci europejskie;

- thumaczenia literackie;

- platformy europejskie.

Część międzysektorowa podzielona jest na trzy segmenty: nagrody UE i europejska stolica kultury oraz instrument finansowy, który zostanie uruchomiony w $2016 \mathrm{r}$. (Osiecki, s. 14). Komponent ten będzie się składać z dwóch części. Pierwsza to instrument gwarancji finansowych, zarządzany przez Europejski Fundusz Inwestycyjny, ułatwiający dostęp małych podmiotów do pożyczek bankowych. Z komponentu międzysektorowego wspierane będą również badania, analizy i lepsze gromadzenie danych w celu poprawy bazy informacyjnej dla ksztaltowania polityki, finansowanie projektów eksperymentalnych w celu zachęcania do współpracy między sektorem audiowizualnym i innymi sektorami kultury i sektorami kreatywnymi (Czym jest, s. 2-4). 
Program „Kreatywna Europa” stanowić będzie proste, dobrze rozpoznawalne i łatwo dostępne narzędzie otwierające drogę osobom zawodowo związanym z sektorem kultury i sektorem kreatywnym w Europie, i to niezależnie od dziedziny artystycznej będącej ich specjalnością; będzie on też oferował możliwości działania na platformie międzynarodowej, zarówno w UE, jak i poza nią.

$Z$ budżetem wynoszącym 1,46 mld euro o $9 \%$ wyższym niż budżet analogicznych programów w latach 2007-2013 szacuje się, że umożliwi to dofinansowanie ok. 250000 artystów i osób zawodowo zajmujących się kulturą, 2000 kin, 800 filmów i 4500 thumaczeń książek. Nowy instrument gwarancji finansowych w ramach programu pozwoli małym podmiotom z sektora kultury i sektora kreatywnego uzyskać dostęp do pożyczek bankowych w kwocie nawet do $750 \mathrm{mln}$ euro (Czym jest, s. 3).

Powyższa kwota będzie sfinansowana w ramach składki do budżetu ogólnego UE przez wszystkie państwa członkowskie, zgodnie $\mathrm{z}$ ich procentowym udziałem $\mathrm{w}$ sumie zasobów własnych UE. 56\% budżetu programu zostanie przeznaczone na wsparcie kinematografii i sektora audiowizualnego w ramach komponentu „Media”, a 31\% na finansowanie części „Kultura”. 13\% budżetu przeznaczona zostanie na część międzysektorową.

Programem zarządza Agencja Wykonawcza ds. Edukacji, Kultury i Sektora Audiowizualnego. W krajach członkowskich pomocniczo powołano biura programu (Creative Europe Desks) zapewniające pomoc dla wnioskodawców (przyszlych beneficjentów) (Czym jest, s. 4).

Polskie Biuro Programu Kreatywna Europa (tzw. Creative Europe Desk) funkcjonuje w ramach struktur Instytutu Adama Mickiewicza, państwowej instytucji kultury podległej Ministrowi Kultury i Dziedzictwa Narodowego.

Creative Europe Desks mają za zadanie: - informowanie o programie i promowanie programu; - zapewnianie podstawowych informacji i pomocy; - stymulowanie współpracy transnarodowej i transgranicznej; - wspieranie Komisji Europejskiej m.in. w działaniach związanych z zapewnianiem właściwych informacji oraz rozpowszechnianiem rezultatów i efektów programu (Czym jest, s. 4-5).

W programie „Kreatywna Europa” nie będą przyjmowane wnioski składane przez osoby indywidualne. Poprzez projekty przygotowywane przez organizacje kulturalne środki finansowe dotrąjednak do około 250 tys. indywidualnych artystów i osób zawodowo związanych z kulturą i sektorem audiowizualnym. Jest to dużo bardziej opłacalny sposób osiagnięcia wyników i trwałych skutków. Komisja ocenia, że dzięki projektom wspieranym przez program „Kreatywna Europa” uda się dotrzeć - bezpośrednio lub pośrednio - do milionów osób (Kreatywna Europa, s. 2).

Podmioty wnioskując o dotacje muszą mieć zarejestrowaną działalność, jak i doświadczenie w dziedzinie, w ramach której składają aplikacje. Za wyjątkiem festiwali filmowych, budowania publiczności, edukacji filmowej i warsztatów, gdzie wnioskować mogą również zarejestrowane fundacje i stowarzyszenia (Osiecki, s. 14).

\section{Zakończenie}

Kultura i dyplomacja kulturalna to sfera kompetencji uzupełniających w ramach systemu decyzyjnego Unii Europejskiej. Autorka tej analizy ma nadzieję, że udało się 
jej wykazać, że nie jest to najważniejszy obszar aktywności wspólnoty instytucji i państw, ale coraz istotniejszy dla zachowania stabilności wewnętrznej Unii. Działania podejmowane w tym obszarze mogą przyczynić się do wsparcia rozwoju społecznego Europy poprzez wzmocnienie międzynarodowej współpracy sektorów kultury i kreatywnych/audiowizualnych. Do tego dochodzi wspieranie działań na rzecz ochrony i propagowania europejskiej różnorodności kulturowej i językowej (Projekt Decyzji, s. 2).

W ujęciu subsydiarnym kultura tworzy sieć pozytywnych interakcji, które przyczyniają się do wzmacniania innych sfer i polityk Unii Europejskiej. Dotyczy to głównie czterech swobód Rynku Wewnętrznego, obywatelstwa UE oraz Przestrzeni Wolności, Bezpieczeństwa i Sprawiedliwości.

Analiza wielu wątków badawczych wyróżnionych w treści tego artykułu naukowego prowadzi do wyróżnienia kilku wniosków:

- koniecznym staje się wymuszenie na państwach członkowskich przygotowania długoterminowych strategii rozwoju, opartych na kulturze;

- należy wypracować katalog zasad i kryteriów programowych w zakresie sektora kultury i sektorów kreatywnego i audiowizualnego;

- istotnym uzupełnieniem dla programów, inicjatyw i projektów z zakresu kultury w UE jest dyplomacja kulturalna realizowana na wielu szczeblach, m.in. poprzez: - Europejską Shużbę Działań Zewnętrznych; - przedstawicielstwa krajowe Komisji Europejskiej i Parlamentu Europejskiego; - Creative Europe Desk; - samorządowców i społeczników skupionych w Komitecie Regionów i Komitecie Ekonomiczno-Społecznym;

- udział w programach i inicjatywach UE musi opierać się na otwartości bez wykluczania środowisk i społeczności;

- nie da się sterować kulturą w Europie bezpośrednio z Brukseli czy Strasburga;

- w kreowanie polityki kulturalnej UE, nie wyłączając dyplomacji kulturalnej bardziej niż dotąd powinny zostać włączone samorządy;

- kultura w UE to nie tylko kultura wysoka, ale także kultura masowa - w zwiazku z tym należy dotrzeć z dobrami kultury do szerszego kręgu odbiorców i zwiększyć ich oddziaływanie na edukację i zachowania społeczne obywateli UE;

- kultura wzmacnia u obywateli europejskich, w szczególności u młodych ludzi, poczucie przynależności do Unii, oparte na wspólnych wartościach oraz elementach europejskiej historii i dziedzictwa kulturowego;

- kultura ma wymiar integracyjny i równoważy tożsamość narodową z tożsamością europejska. Eksponuje walory różnorodności krajowej i regionalnej, ale także udowadnia, że może łączyć i harmonizować wspólnotowy dialog międzykulturowy;

- należy zachęcać do upowszechniania dobrych praktyk (doświadczeń), zwłaszcza w celu zagwarantowania wartości dodanej działań kulturalnych na poziomie europejskim;

- w system zarządzania kulturą w UE powinni zostać włączeni niezależni eksperci.

\section{Bibliografia}

Bednarek S. (red.), (2002), Kongres Kultury Polskiej 2000, Wydawnictwo DTSK Silesia, Warszawa-Wrocław. 
Czachór Z. (2004), Zmiany i rozwój w systemie Unii Europejskiej po Traktacie z Maastricht, Wydawnictwo Atla 2, Wroclaw.

Czym jest Kreatywna Europa? (2014) Materiał informacyjny na temat Programu Kreatywna Europa,

Departament Wspólpracy z Zagranica, Ministerstwo Kultury i Dziedzictwa Narodowego,

Warszawa.

Decyzja nr 1622/2006/WE Parlamentu Europejskiego i Rady z dnia 24 października 2006 r. ustanawiajaca dzialanie Wspólnoty na rzecz obchodów ,Europejskiej Stolicy Kultury” w latach 2007-2019, Dziennik Urzędowy Unii Europejskiej L 304/1, 3.11.2006.

Decyzja Parlamentu Europejskiego i Rady nr 1194/2011/UE z dnia 16 listopada 2011 r. ustanawiajaca dzialanie Unii Europejskiej na rzecz Znaku Dziedzictwa Europejskiego, Dziennik Urzędowy Unii Europejskiej L 303/1, 22.11.2011.

Dyplomacja kulturalna UE potrzebuje nowego impulsu, Komunikat prasowy, Komisja Europejska, Bruksela 10 czerwca 2014 r.

Komunikat Komisji: „Europa 2020. Strategia na rzecz inteligentnego i zrównoważonego rozwoju sprzyjajacego wlaczeniu spotecznemu, $\operatorname{KOM(2010)} 2020$ wersja ostateczna, Bruksela, 3.03.2010.

Kreatywna Europa: najczęściej zadawane pytania (2013), notatka prasowa, Komisja Europejska, Bruksela/Strasburg 19 listopada 2013.

Osiecki A. (2014), Miliony euro dla przedsiębiorstw z sektorów audiowizualnego i kreatywnych, "Rzeczpospolita", 3 listopada.

Prawelska-Skrzypek G. (2003), Polityka kulturalna polskich samorzadów. Wybrane zagadnienia, Wydawnictwo Uniwersytetu Jagiellońskiego, Kraków.

Projekt Decyzji Parlamentu Europejskiego i Rady ustanawiajacej dziatanie UE na rzecz Europejskiej Stolicy Kultury na lata 2020-2033 (pierwsze czytanie), COM(2012) 407, Rada ds. Edukacji, Młodzieży, Kultury i Sportu (EYCS), 16 maja 2013 r.

Rozporzqdzenie Parlamentu Europejskiego i Rady (UE) nr 1295/2013z dnia 11 grudnia 2013 r. ustanawiajace program ,Kreatywna Europa” (2014-2020) i uchylajace decyzje nr 1718/2006/WE, $n$ r 1855/2006/WE i $n r$ 1041/2009/WE, Dziennik Urzędowy Unii Europejskiej L 347/221, 20.12.2013.

Rozporzqdzenie Rady (UE) nr 390/2014 z dnia 15 kwietnia 2014 r. ustanawiajace program ,Europa dla obywateli" na lata 2014-2020, Dziennik Urzędowy Unii Europejskiej L 115/3, 17.04.2014.

Survey shows fall in cultural participation in Europe, press release, European Commission, Brussels, 4 November 2013.

Throsby D. (2010), Ekonomia i kultura, Narodowe Centrum Kultury, Warszawa.

Waluch K. (2004), Polityka kulturalna Unii Europejskiej, Szkoła Wyższa w Płocku, Płock.

Zrozumieć politykę Unii Europejskiej-Kultura i polityka audiowizualna (2013), Dyrekcja Generalna ds. Komunikacji Społecznej, Komisja Europejska, Urząd Publikacji Unii Europejskiej. Luksemburg.

\section{Streszczenie}

Zamierzeniem autorki niniejszego artykułu jest naukowa analiza wpływu kultury i dyplomacji kulturalnej Unii Europejskiej na pobudzanie i stymulowanie procesu integracji Europy, który pozostaje dziś w nieustannym zaburzeniu i braku stabilności. Chodzi tu o problemowe podejście do unijnych strategii zmiany i rozwoju, w tym strategii „Europa 2020” - na rzecz inteligentnego i zrównoważonego rozwoju sprzyjającego włączeniu społecznemu, które zakładają realizację 
wielu nowych unijnych wspólnotowych inicjatyw i rozwiązań praktycznych, także tych dotyczących sektora kultury oraz sektora kreatywnego i audiowizualnego. Unia Europejska po roku 2020 zamierza być gotowa do osiągnięcia wysokiego stopnia zatrudnienia i wydajności oraz większej spójności społecznej. Aby to było realne Unia musi zapewnić bardziej atrakcyjne warunki ramowe dla innowacji i kreatywności. Pod tym względem sektor kultury oraz sektor kreatywny i audiowizualny są źródłem nowatorskich pomysłów, które mogą zamienić się w produkty i usługi przyczyniające się do wzrostu gospodarczego i tworzenia miejsc pracy, pomagając stawić czoła kryzysowi i problemom społecznym.

Kryzys gospodarczy i społeczny w Europie rozprzestrzenia się również na świat kultury. Identyfikujemy tu katalog trudno rozwiązywalnych problemów związanych z rozdrobnieniem sfery kultury i jego wytworów, globalizacją i digitalizacją, niedoinwestowaniem, niewłaściwą ochroną własności intelektualnej i praw autorskich oraz niewystarczającą międzynarodową współpracą kulturalną.

Slowa kluczowe: Unia Europejska, polityka kulturalna, kultura, dyplomacja kulturalna, Kreatywna Europa

\title{
Culture and cultural diplomacy of the European Union - the example of the Creative Europe Programme. A political science analysis
}

\begin{abstract}
Summary
The intention of the author of this paper is to present a scientific analysis of the influence of culture and the cultural diplomacy of the European Union on the animation and stimulation of Europe's integration process, which is in a constant state of perturbation and lack of stability. It examines the problem-related approach to the European Union's change and development strategy, including the „Europe 2020" strategy for smart, sustainable and inclusive growth, which envisages the implementation of many new communal initiatives and practical solutions introduced by the European Union, including ones that concern both the cultural sector and the creative and audiovisual sector. The European Union, from 2020 onwards, intends to be ready to reach a high level of employment and efficiency, and a higher level of social integration. To enable this, the European Union must ensure attractive framework conditions for innovation and creativity.

In that respect, the cultural sector and the creative and audiovisual sector are the source of groundbreaking ideas which may develop into products and services that could contribute to economic growth and job creation, thereby fighting the crisis and social problems. The economic and social crisis in Europe has also been influencing the world of culture. A series of problematic issues associated with the fragmentation of culture and its inventions are identified, including globalisation and digitalisation, underinvestment, inadequate protection of intellectual property and copyright, and insufficient international cultural cooperation.
\end{abstract}

Key words: European Union, cultural policy, culture, cultural diplomacy, Creative Europe 
